\title{
Stress and Job performance: A study on banking sector of Northern region of Sri Lanka
}

\author{
Chathuni Jayasinghe ${ }^{1}$ and M.V.S. Mendis ${ }^{2}$
}

${ }^{1}$ Senior Lecturer, Department of Human Resource Management, University of Kelaniya, Sri Lanka. Email: cha.jayasinghe@gmail.com

${ }^{2}$ Assistant Lecturer, Department of Human Resource Management, University of Kelaniya, Sri Lanka Email: virangisonali2@gmail.com

\begin{abstract}
Modern day business organizations that are operate in complex and demanding markets are often create stress among its employees. Some argue that a certain level of stress is vital for people to achieve greater heights. Others think they will perform much efficiently if they are allowed to work under minimal stress. However, organizations are designing their job roles to get that extra punch from the human resources; and those who capable of handling such complexities will be rewarded. As such, this study was carried out in the Northern region of Sri Lanka, with the primary objective of understanding the effect of stress of bank employees and its impact over performance. Secondly, this research is trying to identify the effect of stress relate to job, organizational and individual factors and their relationships over performance.

Above objectives are achieved with the techniques; correlations and regression. Correlations and coefficient is carried out to determine the relationship between variables. To test the effect of stress over performance, a regression analysis is carried out. Further, revealed that the relationship between stress and performance is negative and concluded that the stress is impacting over the performance of the employees of bank industry.
\end{abstract}

Key words: Stress, Performance, Bank Industry, Sri Lanka

\section{Introduction}

Stress is a complicated model. Stress is the response of a person to a stimulus that disturbs physical or mental equilibrium. In other words stress is the challenge or a threat to peoples' wellbeing. Although some stresses are good and make you motivate; most others are bad and undermine both mental and physical health. To make the best use of people as a valuable resource of the organization, attention must be given to the relationship between staff and the nature of their jobs. The organization's work and the design of jobs can have a significant effect on staff. In this connection, the level of stress is also an important factor that may have impact on the employees' behaviour. An adverse level of stress affects overall performance of the 
organization. Further, from the employees' point of view their stress is caused not only from the organizational factors but also from their individual factors such as family problem, death of close family member etc. Therefore to get an efficient outcome, organization should appropriately administer the level of stress. In order to achieve this objective, all the factors which lead to stress should be properly managed. The level of stress is differed from a person to another. Positive stress will bring eagerness and enthusiasm to life, and negative stress will destroy the momentum of life. The impact of stress over the performance of employees' is an interesting combination. Job performance refers to whether an employee does his/her job well or not. Job performance consists of behaviors that employees do in their jobs that are relevant to the goals of the organization (Campbell, McCloy, Oppler and Sager, 1993). Success of the organization depends on the performance of the employees. Most employees feel they will perform more effectively and efficiently when they are allowed to work with autonomy and lesser stress. On the other hand, when there is a higher stress, often results an increase level of staff turnover, absenteeism and work environment disputes.

Northern region of Sri Lanka was heavily affected by the thirty years of ethnic war. However, with the end of the civil war in 2009, most of the banks \& financial institutions penetrated into the northern region by offering competitive products and financial services, increasing the competition. This situation compelled all the banks to focus on improving the service standards to retain the customer base. Thereby the targets given to employees have been increased. Extensive marketing campaigns, promotions throughout the months are a normal scenario in this region, thus prevented these employees been travelled back to their homes even during the weekend. This has hugely affected over the stress levels of those employees. Although the conditions are such, in order to capitalize over the new market opportunities, banks are continuously giving targets to its employees and pushing behind towards increasing of numbers. Due to insufficient staff, employees are loaded with heavy workload and assigned to multiple tasks with strict deadlines. Management see the risk of decreasing service levels of the bank employees and their motivational levels, and in a situation where unable to identify or calculate the magnitude of it. The staff turnover ratio is high in this region which elaborates the stress level of the employees. Although the number of researches has been done in the field of stress and work stress in their pure extremes, no one is carried out any in relation to financial institutions of Sri Lanka and specifically in relation to banks in Northern Province of Sri Lanka. So this study will focus on whether there is a relationship between stress and employees' job performance in the banking industry of Sri Lanka.

\section{Literature Review}

\subsection{Stress}

Hans Selye first introduced the concept of stress in to the life science in 1936. He defined stress as "The force, pressure, or strain exerted upon a material object or person which resist these forces and attempt to maintain its original state." (Selye, 1956). Stress is ubiquitous in our society. It has become an integral part of everyday living. Stress is an unavoidable consequence of modern living. With the growth of industries, pressure in the urban areas, quantitative growth in population and various problems in day to day life are some of the reasons for increase in stress. Stress is a condition of strain that has a direct bearing on emotions, thought process and 
physical conditions of a person. Steers (1981) indicate that, occupational stress has become an important topic for study of organizational behaviour due to several reasons such as stress has harmful psychological and physiological effects on employees, stress is a major cause of employee turnover and absenteeism, stress experienced by one employee can affect the safety of other employees and by controlling dysfunctional stress, individual and organization can be managed more effectively. During the past decade, the banking sector had under gone rapid and striking changes such as policy changes due to globalization and liberalization, increased competition due to the entrance of more private (corporate) sector banks, downsizing, introduction of new technologies, etc. Because of these changes, the employees in the banking sector are experiencing a high level of stress than ever before. According to French and Caplan \& Jones (1975), pressure of both qualitative and quantitative overload can result in the need to work excessive hours, which is an additional source of stress. Having to work under time pressure in order to meet deadlines is an independent source of stress. Studies show that stress levels increase as difficult deadlines draw near. Stress is often developed when an individual is assigned a major responsibility without proper authority and delegation of power. Interpersonal factors such as group cohesiveness, functional dependence, communication frequency, relative authority and organizational distance between the role sender and the focal persons are important topics in organizational behaviour (Brief, Schuler, \& Van Sell, 1981).

\subsection{Sources of Stress}

The antecedents of stress, or the so-called stressors, affecting today's employees are summarized in the following Figure 1. As shown in it, these causes come from both outside and inside the organization and from the groups that employees are influenced by and from employees themselves.

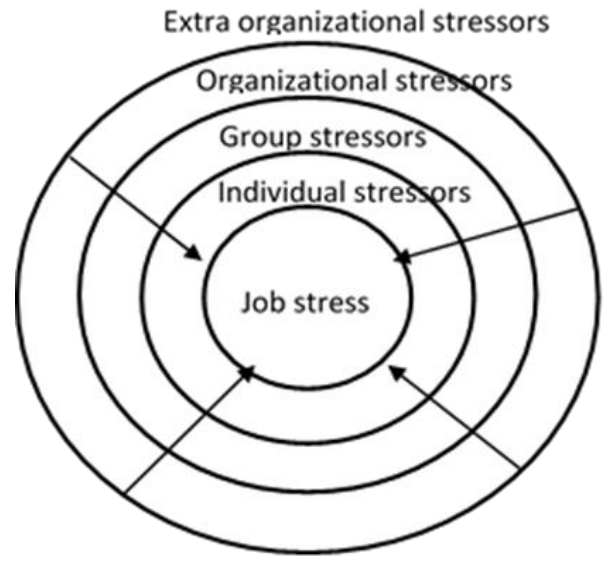

Figure 1: Categories of stressors

\subsubsection{Extra organizational stressors}

Although most analysis of job stress ignore the importance of outside forces and events, it is becoming increasingly clear that these have a tremendous impact. Taking an open-systems perspective of an organization (that is, the organization is greatly affected by the external environment), it is clear that job stress is not limited just to things that happen inside the organization, during working hours.

Extra organizational stressors include things such as societal/ technological change, the family, and relocation, economic and financial conditions, race and class, and residential or community conditions. The phenomenal rate of social and technical change has had a great effect on 
people's lifestyles, and this of course is carried over into their jobs. Although medical science has increased the life spans of people and has eradicated or reduced the threat of many diseases, the pace of modern living has increased stress and decreased personal wellness. It is generally recognized that a person's family has a big impact on personality development. A family situation-either a brief crisis, such as a squabble or the illness of a family member, or long term strained relations with the spouse or children-can act as a significant stressor for employees.

Relocating the family because of a transfer or a promotion can also lead to stress. For most people in recent years, their financial situation has proved to be a stressor. Some stress researchers define these personal life stressors as unresolved environmental demands (for example, family or financial problem) requiring adaptive behaviours in the form of social readjustments. Life's changes may be slow or sudden. These sudden changes have been portrayed in novels and movies as having a dramatic effect on people. These life changes can also directly influence job performance.

Sociological variables such as race, sex and class can also become stressors. More recently, research has found that women experience more psychological distress than men, but men are more prone to severe physical illness. Also, People in the middle and upper classes may have particular or common stressors. The same is true of the local community or region that one comes from. For example, one researcher identified the condition of housing, convenience of services and shopping, neighbourliness, and degree of noise and air pollution as likely stressors.

\subsubsection{Organizational stressors}

Organizational stressors affect large number of employees. Stress in an organization can be due to an insensitive bass, unpleasant co - workers, work over load and the need to complete a task in a limited time. For instance a high pressure environment that places chronic work demands on employees fuels the stress response. In contrast, research provides preliminary support for the idea that participative management can reduce organizational stress.

The office design and general office environment are important organizational level stressors. Research demonstrators are the poor lighting, loud noise, improper placement of furniture and dirty or smelly environment also create stress. Managers are advised to monitor and eliminate these stressors.

Besides the potential stressors that occur outside the organization, there are also those associated with the organization itself. Although the organization is made up of groups and individuals, there is also more macro - level dimensions, unique to the organization that contains potential stressors.

\subsubsection{Group Stressors}

The group can also be a potential source of stress. These group stressors can be categorized into three areas such as lack of group cohesiveness, lack of social support and intra-individual, interpersonal, and inter group conflict.

\subsubsection{Lack of group cohesiveness}


Starting with the historically famous Hawthorne studies, it has become very clear that cohesiveness, or "togetherness", is very important to employees, especially at the lower levels of organizations. If an employee is denied the opportunity for this cohesiveness because of the task design, because the supervisor does things to prohibit or limit it or because the other members of the group shut the person out, the resulting lack of cohesiveness can be very stress - producing.

\subsubsection{Lack of social support}

Employees are greatly affected by the support of one or more members of a cohesive group. By sharing their problems and joys with others, they are much better off. If this type of social support is lacking for an individual, the situation can be very stressful.

\subsubsection{Intra-individual, Interpersonal, and inter group conflict}

Conflict is very closely conceptually linked to stress. Conflict is normally associated with incompatible or hostile acts between intra-individual dimensions such as personal goals or motivational needs/values, between individuals within a group, and between groups.

Group related stressors include factors such as conflict, poor communications, unpleasant relationships, and fear of being ostracized from the group as a valued member working with superiors, peers, or subordinates with whom one does not get along can be a constant source of stress. Some people can deal with misunderstandings and conflicts in an open way and resolve issues as they arise. Many, however, find it difficult to do this and build internal stresses for themselves. When conflicts, poor communications, and unpleasant interactions have to be faced at the work place, individuals try to avoid the stresses by remaining absent as frequently as possible, and even start looking for other jobs.

\subsubsection{Individual Stressors}

Individual level stressors are those directly associated with a person's job duties and his family relationships. Marital difficulties Breaking off a relationship and discipline troubles with children are example of relationship problems that creates stress for employees and that are not left at the front door when they arrive at door. Managers create stress for employees by exhibiting inconsistent behaviours, failing to provide support, showing lack of concern, providing inadequate direction creating a high productivity environment and focusing on negatives while ignoring good performance. In a sense, the categories of stressors discussed so far (extra organizational, organizational, and group) eventually get down to the individual level.

\subsection{Job Performance}

There is no any universally accepted definition for the term "performance". Different managerial experts put the different definitions for these them. In this way Porter and Lawler (1968) have defined job performance as the net effect of a person's effort as modified by this abilities and traits and by his role perceptions. This definition implies that performance in a given situation can be viewed as resulting from the interrelationships between effort, abilities, and traits and role perceptions. Motowidlo (2003) define job performance is based on employee behavior and the outcome is vital for the organizational success. Muchinsky (2003) explained job performance as a combination of employee's behaviors. Further he described that it can be monitored, measured 
and evaluated as outcomes at employee level and linked with the organizational goals. Therefore job performance is a vital determinant for organizational success.

\subsection{Job Stress and Job Performance}

According to Singh (2001), when there is no stress, job challenges are absent and performance tends to be low. As stress increases, performance tends to increase, because stress helps a person call up resources to meet job requirements. It is a healthy stimulus that encourages employees to respond to challenges. Eventually stress reaches a plateau that corresponds approximately with a person's top day-to-day performance capability. At this point additional stress tends to produce no more improvement. Finally, if stress becomes too great, performance begins to decline, because stress interferes with it (Table 1).

Table 1 - Stress Levels and Consequences

\begin{tabular}{|l|l|l|l|}
\hline Stress Level & \multicolumn{1}{|c|}{ Low Stress } & \multicolumn{1}{c|}{ Optimum Stress } & \multicolumn{1}{c|}{ High Stress } \\
\hline Reactions & Boredom/Apathy & High Energy & Exhaustion \\
Behaviours & $\begin{array}{l}\text { Low motivation } \\
\text { Careless mistakes } \\
\text { Psychological withdrawal } \\
\text { Physical withdrawal } \\
\text { Inactivity }\end{array}$ & $\begin{array}{l}\text { Heightened perception } \\
\text { High Involvement }\end{array}$ & $\begin{array}{l}\text { Anxiety \& Nervousness } \\
\text { Indecisiveness } \\
\text { Bad Judgment }\end{array}$ \\
$\begin{array}{l}\text { Performance } \\
\text { Health } \\
\text { effects }\end{array}$ & $\begin{array}{l}\text { Low Performance } \\
\text { Dull Health }\end{array}$ & $\begin{array}{l}\text { High Performance } \\
\text { Good Health }\end{array}$ & $\begin{array}{l}\text { Poor Performance } \\
\text { Insomnia } \\
\text { Psychosomatic Illnesses }\end{array}$ \\
\hline
\end{tabular}

Ziauddin, Riaz, Farooq \& Tahir (2010) explored stress as the main cause behind the low satisfaction of employees about the job and low job commitment which ultimately hinders the overall performance of the working organizations. Robert Marie \& Mark (2009) highlighted that sick leaves, high labour turnover and early retirements are the worst results of job/work related stress. Rehman, Aslam, Hasan, Waheed \& Imran (2010) also revealed stress as the main cause of employees' poor health and reduced performance around the globe.

\subsection{Conceptual Framework}

After the careful study of literature review, the following conceptual model is formulated to depict the relationship between stress and performance (Figure 1). The framework shows three (3) independent variables such as job related factors of stress, organization factors of stress and individual factors of stress. Job performance of the employees is the dependent variable. 
Independent variables

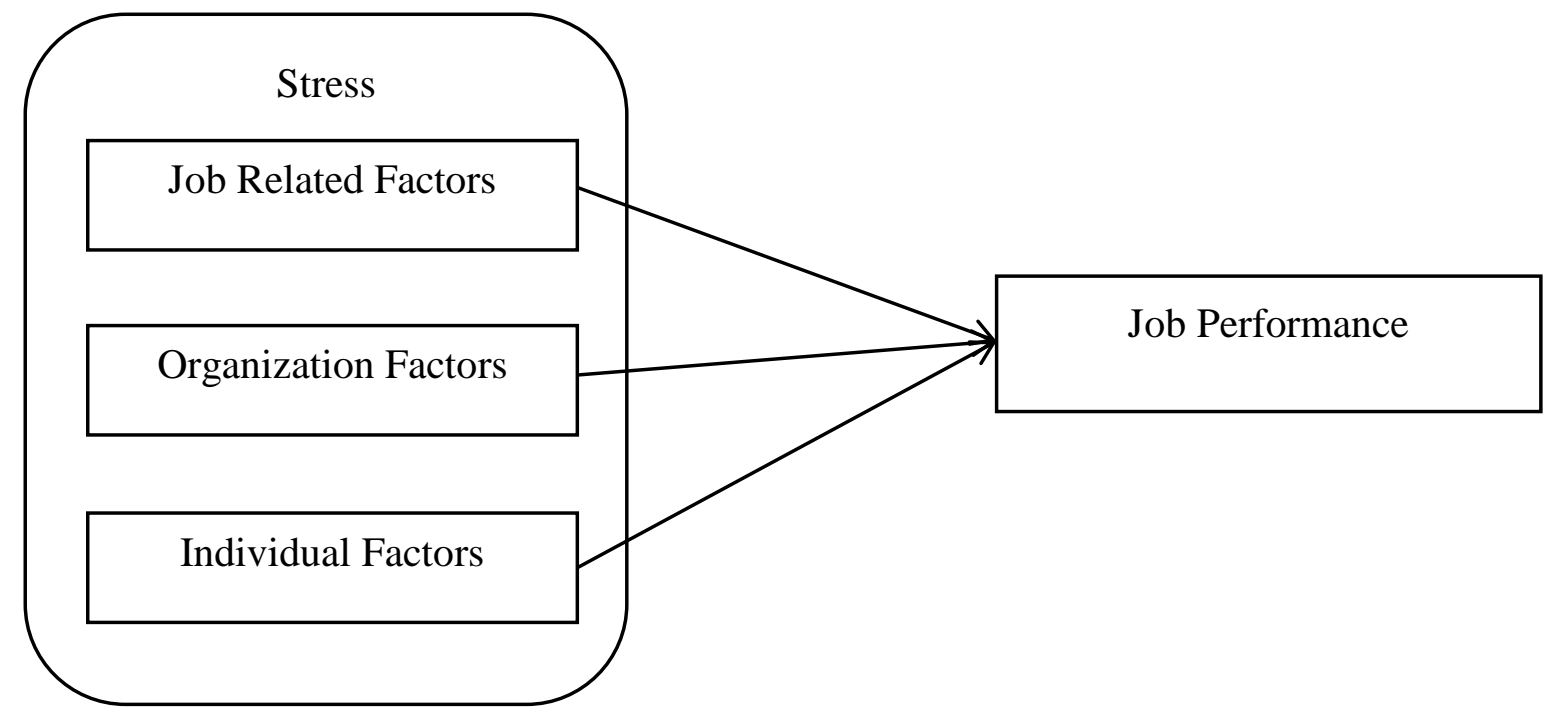

\section{Hypotheses}

Based on the above conceptual model the following hypotheses $(\mathrm{H})$ has been formulated for this study.

H1: There is a significant relationship between job related stress and job performance of employees

$\mathrm{H} 2$ : There is a significant relationship between organizational stress and job performance of employees.

H3: There is a significant relationship between individual stress and job performance of employees.

H4: There is a significant relationship between stress and job performance of employees.

\section{Research Methodology}

The study relied on survey method as the researchers assumed it to be the most appropriate method according to the nature of the study. The sample for this study is 125 banking employees in the bank industry. The total number of employees was 176 in all the branches of the selected bank in the Northern region. The data collection was done by using a self-administrated structured questionnaire. The questionnaire consists of 52 questions. Five point Likert type scale has been used in the questionnaire to measure stress and job performance such as, 5 for strongly agree, 4 for agree, 3 for neutral, 2 for disagree and 1 for strongly disagree have been given in order to analyze data. The questions are designed based on literature collected (Selye, 1993; Ferris, Bergin \& Wayne, 1988). Questions regarding the personal details cover age, marital status, dependents, experience and education etc.To test the hypotheses, Pearson's product moment correlation analysis and multivariate analysis were used. The statistical computer package SPSS version 20.0 was utilized to analyze the data. The Cronbach's coefficient was used to get the inter item consistency reliability (Walsh, 1995). Cronbach's alphas were 0.710 for stress and 0.701 for job performance suggesting that each instrument's internal consistency was satisfactory. 


\section{Results}

\subsection{Testing of Hypotheses}

The results of Pearson's product moment correlation analysis used to test the hypotheses are presented in the Table 2. The desired level of significance is 0.01. As these hypotheses are non directional hypotheses, two-tailed test was used.

Table 2: Pearson Correlation for all selected independent variables and dependent variable

\begin{tabular}{|l|c|c|}
\hline \multicolumn{1}{|c|}{ Independent variables } & $\begin{array}{c}\text { Dependent variable } \\
\text { ( Job performance) }\end{array}$ & Sig. \\
\hline Job related stress & $-0.488^{* *}$ & 0.000 \\
\hline Organizational stress & $-0.616^{* *}$ & 0.000 \\
\hline Individual stress & $-0.602^{* *}$ & 0.000 \\
\hline Stress & $-0.729^{* *}$ & 0.000 \\
\hline
\end{tabular}

**. Correlation is significant at the 0.01 level (2-tailed).

The analysis of the results indicate a negative correlation between job related stress and job performance $(\mathrm{r}=-0.488)$ and is significant at 0.01 . There is a negative relationship between organizational stress and performance. The correlation coefficient $(r=-0.616)$ is significant at 0.01 . The negative relationship between individual stress and performance $(r=-0.602)$ and is significant at 0.01 . The stress reveal its significant negative correlation with performance $(\mathrm{r}=-$ 0.729 ) at $\mathrm{p}=0.01$ shows that employees' performance is highly correlates to the stress they have been undergone.

Multivariate analysis evaluates the simultaneous effects of all the independent variables on dependent variable. The results of regressing the three independent variables against the dependent variable employees' job performance are shown in the Table 3.

Table 3: Aggregate impact of the stress factors on job performance

\begin{tabular}{|c|c|c|c|c|c|}
\hline $\mathrm{R}$ & $\mathrm{R}^{2}$ & Adjusted $\mathrm{R}^{2}$ & $\begin{array}{c}\text { Std. error of } \\
\text { the estimate }\end{array}$ & $\mathrm{F}$ & Sig.F \\
\hline 0.735 & 0.540 & 0.529 & 0.30318 & 47.426 & 0.000 \\
\hline
\end{tabular}

The adjusted square of the multiple $\mathrm{R}$ is 0.529 indicating that the $52.9 \%$ of variance in job performance is explained by the three independent variables jointly. There is statistical evidence to claim that three independent variables have significantly explained the $52.9 \%$ of the variance in job performance of the selected domain.

\section{Discussion}

The success of the organization depends on the performance of the employees. The employee performance is affected by many factors. Particularly, employees' stress mostly affects their work performance. The stress can cause dissatisfaction; by this employees cannot perform their 
work successfully and effectively. As hypothesized it was found that there are significant relationships between jobs related stress, organizational stress and individual stress and job performance of employees. The overall relationships of different elements of stress showed that organizational stress has the strongest negative relationship with job performance. Analysis of the collected data revealed that stress has a significant impact on the employees' performance.

The sample indicated that majority of the banking employees are male (72.8\%). And the ages of $41.6 \%$ of employees are in the range of $26-35$ years and $44.8 \%$ of the employees have $4-7$ years' experience. $70.4 \%$ of the employees are General Certificate in Education (Advanced Level) qualified. There is $36.8 \%$ of employees responsible for cash operations in their job role. Further majority of employees are single $(69.6 \%)$ among the employees considered for the study.

\section{Conclusion}

The main objective of this study was to understand the relationship between stress and performance of employees in banking industry of Sri Lanka. For this purpose, the study covered fourteen branches of a selected bank from northern region in Sri Lanka. In line with this research, it is found that stress might affect to reduce job performance. According to the analysed data, employees stress has an impact on their job performance. That is, a change at the stress level experienced by employees affects to their job performance. Further there is a negative relationship between employees' stress level and their job performance. Strong correlations exist between elements of stress and job performance of employees. The regression analysis of the data shows that the coefficient of determination adjusted $R$. square $=0.529$, so, it can be concluded that $52.9 \%$ of the variability in employees' job performance is accounted for by the variables in this model. Most of the organizations do not give importance to the stress undergo by their employees; this study will give them ample reasons to consider stress of employees' as an important factor in increasing employees' performance.

\section{Recommendation}

Stress experienced by employees should be managed to improve their performance. Thereby in order to reduce adverse stress managers should provide additional employees to manage the crowded branches, improve easy two way communication between managers and staff, introduce more recreational activities such as indoor games, TV room and internet facilities for each employee. Further the staff should be allowed to get advices from their supervisors and connect with other peers. A strong support system will buffer them from the negative effects of stress. Further the organization should create a supportive organizational climate and counselling facility should be readily available for the staff. It is recommended to create a stress free environment for the employees who will thereby improve their performance up to the satisfactory level of the management

\section{References}

Alder, G.S. (2001). Employee reaction to electronic performance monitoring: A consequence of organizational culture, Journal of High Technology Management Research, 17/6, 323327.

Arnold, H. J., Feldman, D. C., \& Hunt, G. (1992). Organizational behaviour: a Canadian perspective. McGraw-Hill Ryerson. 
Brief, A. P., Schuler, R. S., \& Van Sell, M. (1981). Managing job stress. Little, Brown.

Beehr, T. A. (1985). Organizational stress and employee effectiveness: A job characteristics approach. Human stress and cognition in organizations, 57-82.

Beehr, T. A., \& Newman, J. E. (1978). Job stress, employee health, and organizational effectiveness: A facet analysis, model, and literature review. Personnel psychology, 31(4), 665-699.

Campbell, J. P., McCloy, R. A., Oppler, S. H. and Sager, C. E. (1993) 'A theory of performance', in C. W. Schmitt and W. C. A. Borman (eds), Personnel Selection in Organizations. San Francisco: JosseyBass, pp. 35-70

Caplan, R. D., \& Jones, K. W. (1975). Effects of work load, role ambiguity, and type A personality on anxiety, depression, and heart rate. Journal of applied psychology, 60(6), 713.

Cooper, C. L. (Ed.). (1998). Theories of organizational stress. OUP Oxford.

Ferris, G. R., Bergin, T. G., \& Wayne, S. J. (1988). Personal characteristics, job performance, and absenteeism of public school teachers. Journal of Applied Social Psychology, 18(7), 552-563.

Freudenberger, H. J. (1998). Stress and Burnout and their implication in the Work Environment. The encyclopedia of occupational health and safety (pp. 5.15-5.17). Geneva, Switzerland: International Labor Office.

Greenhaus, J. H., \& Beutell, N. J. (1985). Sources of conflict between work and family roles. Academy of management review, 10(1), 76-88.

Levi, L. (1998). Preface: Stress in Organizations-Theoretical and empirical approaches. Theories of Organizational Stress, Oxford University Press, New York, NY.

Motowidlo, S. J. (2003). Job performance. Handbook of psychology

Muchinsky, P. M. (2003). Psychology applied to work (7th ed.). Belmont, CA: Thomson Wadsworth.

Rehman, Aslam.K, Hasan, A. Waheed, A \&Imran, A (2010) Stress in banker's life: demandscontrol model as predictors of employee's activity participation, African Journal of Business Management, 4(9), 1679-1690.

Robert, K. Marie, M \& Mark, M (2009) HEALTH AND SAFETY EXECUTIVE Management Standards and stress-related work outcomes, occupational medicine 59, 574-579.

Sanders, A. (1983). Towards a model of stress and human performance. Acta psychologica, 53(1), 61-97.

Selye H, (1975): Stress without Distress, JP Lippicott Company New York. 
Selye H, (1976): The stress of life (Rev.ed) McGraw-Hill, New York.

Selye H, (1993): $\quad$ History of the stress concept, in L.Goldberger and S.Breznitz,eds ., The hand book of stress, $\left(2^{\text {nd }}\right.$ edition $)$, The Free Press, New York.

Selye, H (1956). The Stress of life New York : McGraw-Hill, New York.

Singh, N. (2001). Organisational Behaviour: Concepts, Theory and Practices: Managing People and Organisations in the 21 st Century. Deep and Deep Publications.

Steers, R. M. (1981). Introduction to organizational behavior. Goodyear Publishing Company.

Porter, L. W., \& Lawler, E. E. (1968). Managerial attitudes and performance.

Ziauddin, Riaz. K, Farooq.J \& Tahir, H. (2010) The impact of employees job stress on organizational commitment, European Journal of Social Sciences 13(4), 617-622 